\title{
Allopatric speciation in ticks: genetic and reproductive divergence between geographic strains of Rhipicephalus (Boophilus) microplus
}

\author{
Marcelo B Labruna ${ }^{1}$, Victoria Naranjo ${ }^{2}$, Atilio J Mangold ${ }^{3}$, \\ Carolina Thompson ${ }^{3}$, Agustín Estrada-Peña ${ }^{4}$, Alberto A Guglielmone ${ }^{3}$, \\ Frans Jongejan ${ }^{5,6}$ and José de la Fuente*2,7
}

\begin{abstract}
Address: ${ }^{1}$ Departamento de Medicina Veterinária Preventiva e Saúde Animal, Faculdade de Medicina Veterinária e Zootecnia, Universidade de São Paulo, São Paulo, SP, 05508-270, Brazil, ${ }^{2}$ Instituto de Investigación en Recursos Cinegéticos IREC (CSIC-UCLM-JCCM), Ronda de Toledo s/n, 13005 Ciudad Real, Spain, ${ }^{3}$ Instituto Nacional de Tecnología Agropecuaria, Estación Experimental Agropecuaria Rafaela, CC 22, CP 2300 Rafaela, Santa Fe, Argentina, ${ }^{4}$ Facultad de Veterinaria, Universidad de Zaragoza, Miguel Servet 177, 50013-Zaragoza, Spain, ${ }^{5}$ Utrecht Centre for Tick-borne Diseases (UCTD), Department of Infectious Diseases and Immunology, Faculty of Veterinary Medicine, Utrecht University, Yalelaan 1, 3584CL, Utrecht, The Netherlands, 'Department of Veterinary Tropical Diseases, Faculty of Veterinary Science, University of Pretoria, Private Bag X04, 0110 , Onderstepoort, South Africa and ${ }^{7}$ Department of Veterinary Pathobiology, Center for Veterinary Health Sciences, Oklahoma State University, Stillwater, OK 74078, USA

Email: Marcelo B Labruna - labruna@usp.br; Victoria Naranjo - MVictoria.Naranjo@uclm.es; Atilio J Mangold - AMangold@rafaela.inta.gov.ar; Carolina Thompson - cthompson@rafaela.inta.gov.ar; Agustín Estrada-Peña - aestrada@unizar.es;

Alberto A Guglielmone - aguglielmone@rafaela.inta.gov.ar; Frans Jongejan - F.Jongejan@uu.nl; José de la

Fuente* - jose.de_la_fuente@okstate.edu

* Corresponding author
\end{abstract}

Published: 25 February 2009

BMC Evolutionary Biology 2009, 9:46 doi:10.1 186/147|-2/48-9-46

This article is available from: http://www.biomedcentral.com/I47I-2/48/9/46

(C) 2009 Labruna et al; licensee BioMed Central Ltd.

This is an Open Access article distributed under the terms of the Creative Commons Attribution License (http://creativecommons.org/licenses/by/2.0), which permits unrestricted use, distribution, and reproduction in any medium, provided the original work is properly cited.

\begin{abstract}
Background: The cattle tick, Rhipicephalus (Boophilus) microplus, economically impact cattle industry in tropical and subtropical regions of the world. The morphological and genetic differences among $R$. microplus strains have been documented in the literature, suggesting that biogeographical and ecological separation may have resulted in boophilid ticks from America/Africa and those from Australia being different species. To test the hypothesis of the presence of different boophilid species, herein we performed a series of experiments to characterize the reproductive performance of crosses between R. microplus from Australia, Africa and America and the genetic diversity of strains from Australia, Asia, Africa and America.
\end{abstract}

Results: The results showed that the crosses between Australian and Argentinean or Mozambican strains of boophilid ticks are infertile while crosses between Argentinean and Mozambican strains are fertile. These results showed that tick strains from Africa (Mozambique) and America (Argentina) are the same species, while ticks from Australia may actually represent a separate species. The genetic analysis of mitochondrial I2S and I6S rDNA and microsatellite loci were not conclusive when taken separately, but provided evidence that Australian tick strains were genetically different from Asian, African and American strains.

Conclusion: The results reported herein support the hypothesis that at least two different species share the name R. microplus. These species could be redefined as R. microplus (Canestrini, 1887) (for American and African strains) and probably the old $R$. australis Fuller, 1899 (for Australian strains), which needs to be redescribed. However, experiments with a larger number of tick strains from different geographic locations are needed to corroborate these results. 


\section{Background}

The cattle tick, Rhipicephalus (Boophilus) microplus, is distributed in tropical and subtropical regions of the world [1]. Infestations with $R$. microplus economically impact cattle industry by reducing weight gain and milk production, and by transmitting pathogens that cause babesiosis (Babesia bovis and B. bigemina) and anaplasmosis (Anaplasma marginale) [2,3]. The morphological and genetic differences among $R$. microplus strains have been documented in the literature $[4,5]$. Although Londt and Arthur [6] argued that morphological differences between these strains are too slight to warrant species status, other results provided opposing evidence [7]. These authors demonstrated that hybrids resulting from crossing $R$. (B.) microplus strains from South Africa and Australia were sterile. Thus, R. microplus from South Africa and Australia might be regarded as different species [8].

Contradictory results have been reported after the analysis of different gene loci in $R$. microplus strains collected at different locations. It has been [9] found that the analysis of ribosomal internal transcribed spacer 2 (ITS2) sequences resulted in similar divergence between Australian and South African R. microplus strains and among tick strains from Australia, Brazil, Kenya and South Africa. However, a clear divergence in the acetylcholinesterase sequence between Australian and African/Mexican strains of $R$. microplus has been detected [10]. The mitochondrial $12 \mathrm{~S}$ rDNA divergence between American and African $R$. microplus strains is lower than the divergence between these strains and the R. microplus from Australia and Nepal [11].

These results suggested that biogeographical and ecological separation between boophilid lineages may have resulted in different species of ticks in America/Africa and those from Australia, collectively known as R. microplus, but being actually separate species [11]. To test the hypothesis of the presence of different species in $R$. microplus ticks, herein we performed a series of experiments to characterize the the reproductive performance of crosses between ticks from Australia, Africa and America and the genetic diversity of $R$. microplus strains from Australia, Asia, Africa and America.

\section{Methods}

\section{Tick crosses and fertility analysis}

Tick crosses were conducted using strains originally determined as $R$. microplus from Argentina (ARG), Mozambique (MOZ) and Australia (AUS, Yeerongpilly strain) (Table 1). In experiment I, calves were infested with larvae of ARG and AUS, each strain separately infesting a cotton sleeve (20 cm diameter) glued (Kamar heat detector adhesive, Kamar, Steamboat Springs, CO, USA) to the shaved dorsum skin of two tick-naïve Holstein calves. After 1215 days of infestation, sleeves were opened and engorged nymphs attached to the skin were manually removed from each sleeve and held in an incubator at $34^{\circ} \mathrm{C}$ and 95\% RH for molting. Emerged adults, less than 24 hours from their ecdysis were then sorted to form the infestation male $\times$ female crosses into new sleeves glued to the dorsum of the same calves from where engorged nymphs were collected. Crosses were made with adult ticks from the same strain (AUS $\times$ AUS, and ARG $\times$ ARG; homologous crosses), and with adult ticks from different strains (AUS $\times$ ARG, and ARG × AUS; heterologous crosses) (Table 2). Each cross consisted of 15-20 males and 20-30 females per sleeve. Two additional sleeves, each containing only 20-30 unfed females from each strain were prepared to be the control of virgin females for each strain.

All engorged females recovered from each sleeve (each separate cross) were individually weighed and left in an incubator at $25^{\circ} \mathrm{C}$ and $85 \% \mathrm{RH}$. The total egg mass produced by each female was weighed and its hatchability was determined as described [12]. The egg production efficiency (EPE) was determined as (weight of eggs/weight of the engorged female $) \times 100$ [13]

In experiment II, tick-naïve New Zealand rabbits were infested with larvae from ARG, AUS, and MOZ strains inside a cotton sleeve $(20 \mathrm{~cm}$ diameter $)$ glued to the shaved dorsum skin of the rabbit. At 12-15 days postinfestation, sleeves were opened and engorged nymphs attached to the skin were manually removed from each sleeve and held in an incubator at $34^{\circ} \mathrm{C}$ and $95 \% \mathrm{RH}$ for molting. Emerged adults, less than 24 hours from their ecdysis, were sexed to form the infestation male $\times$ female crosses in sleeves glued to the dorsum of a calf. A total of 12 sleeves were mounted on the calf to encompass the nine possible crosses between the three strains, as well as three additional sleeves for virgin control females for each strain (Table 3). Each cross consisted of 20-25 males and 25-30 females per sleeve, and procedures for recovery and analysis of engorged females recovered from each sleeve were as described for experiment I.

In order to verify successful reproductive compatibility between strains, unfed larvae (20-30 days old) obtained from the crosses (designated as $F_{1}$ larvae) were used to infest a calf for experiment $\mathrm{I}_{-} \mathrm{F}_{1}$ ticks, and another calf for experiment II- $\mathrm{F}_{1}$ ticks (one sleeve used for infestation with larvae generated from each separate cross). The resulting engorged females were processed as previously described.

Feeding periods of ticks from each cross were compared by the non-parametric Mann-Whitney test, whereas engorged female weights and reproductive parameters (which show normal distribution) were compared by the Student $t$-test. Variables were considered significantly different if $P<0.05$. 
Table I: Tick strains used in these studies.

\begin{tabular}{|c|c|c|c|}
\hline Tick species & Geographical origin & Collection date & Genbank accession No. \\
\hline \multirow[t]{2}{*}{ R. microplus } & Quimilí, Argentina & Apr-1998. & 16S: EU918176 \\
\hline & & & I2S: EU921758 \\
\hline \multirow[t]{2}{*}{ R. microplus } & Corichi Grande, Bolivia & Sep-1999 & 16S: EU918177 \\
\hline & & & I2S: EU921759 \\
\hline \multirow[t]{2}{*}{ R. microplus } & Sao Gabriel, Brazil & Oct-2000 & I6S: EU918178 \\
\hline & & & I2S: EU921760 \\
\hline \multirow[t]{2}{*}{ R. microplus } & Ciudad Quesada, Costa Rica & Sep-1998 & I6S: EU918179 \\
\hline & & & I2S: EU92176I \\
\hline \multirow[t]{2}{*}{ R. microplus } & Asunción, Paraguay & Oct-1999 & I6S: EU918180 \\
\hline & & & I2S: EU921762 \\
\hline \multirow[t]{2}{*}{ R. microplus } & Piura, Peru & Jun-2002 & I6S: EU918181 \\
\hline & & & I2S: ND \\
\hline \multirow[t]{2}{*}{ R. microplus } & Rocha, Uruguay & Jun-2002 & I6S: EU918184 \\
\hline & & & 12S: $\overline{\text { EU921763 }}$ \\
\hline \multirow[t]{2}{*}{ R. microplus } & Australia (A). DDT-susceptible strain & Oct-1998 & I6S: EU918185 \\
\hline & & & I2S: $\overline{\text { EU921767 }}$ \\
\hline \multirow[t]{2}{*}{ R. microplus } & Australia (B). DDT-resistant strain & Oct-1998 & I6S: EU918186 \\
\hline & & & I2S: EU921768 \\
\hline \multirow[t]{2}{*}{ R. microplus } & Australia (C). Yeerongpilly strain & $1950 \mathrm{~s}$ & I6S: EU918192 \\
\hline & & & I2S: EU921769 \\
\hline \multirow[t]{2}{*}{ R. microplus } & Bourail, New Caledonia & 2006 & 16S: EU918191 \\
\hline & & & I2S: EU921770 \\
\hline \multirow[t]{2}{*}{ R. microplus } & Jakarta (Batavia), Indonesia & 1951 & 16S: EU918189, EU918190 \\
\hline & & & I2S: EU92177| \\
\hline \multirow[t]{2}{*}{ R. microplus } & Mozambique & 2003 & I6S: EU918191 \\
\hline & & & I2S: EU921766 \\
\hline \multirow[t]{2}{*}{ R. microplus } & Limpopo, South Africa & Jul-2003 & I6S: EU918182 \\
\hline & & & I2S: EU921764 \\
\hline \multirow[t]{2}{*}{ R. microplus } & Tanzania & 1973 & I6S: EU918183 \\
\hline & & & I2S: EU921765 \\
\hline \multirow[t]{2}{*}{ R. microplus } & Izatnagar, India & 2008 & 16S: EU918188 \\
\hline & & & I2S: EU921770 \\
\hline \multirow[t]{2}{*}{ R. annulatus } & Egypt & 1961 & I6S: ND \\
\hline & & & I2S: EU921773 \\
\hline \multirow[t]{2}{*}{ R. decoloratus } & Limpopo, South Africa & Jul-2003 & I6S: EU918193 \\
\hline & & & I2S: $\overline{\text { EU921774 }}$ \\
\hline
\end{tabular}

Abbreviation: ND, not done. 
Table 2: Results of experiment I in which calves were infested with crosses of adult ticks of Rhipicephalus (Boophilus) microplus strains from Australia (AUS) and Argentina (ARG).

\begin{tabular}{|c|c|c|c|c|c|c|c|}
\hline $\begin{array}{c}\text { Cross }^{+} \\
(\text {male } \times \text { female) }\end{array}$ & $\begin{array}{l}\text { Engorged female } \\
\text { weight }(\mathrm{mg})^{*}\end{array}$ & $\begin{array}{l}\text { Feeding period } \\
\text { (days)* }\end{array}$ & $\begin{array}{l}\text { No. engorged females } \\
\text { that oviposited (\%) }\end{array}$ & Egg mass weight (mg)* & EPE* & $\%$ egg hatching* & F, fertility@ \\
\hline$A R G \times A R G$ & $267.5 \pm 38.1$ a & $21.5 \pm 0.5^{\&} \mathrm{a}$ & $26(100)$ & $129.4 \pm 28.4 \mathrm{a}, \mathrm{e}$ & $48.6 \pm 8.9 \mathrm{a}$ & $93.1 \pm 20.5 \mathrm{a}$ & Yes \\
\hline AUS $\times$ AUS & $196.8 \pm 43.1 \mathrm{~b}$ & $19.8 \pm 0.4^{\& b}$ & $52(83.9)$ & $69.7 \pm 25.6 b$ & $34.3 \pm 11.2 \mathrm{~b}$ & $82.5 \pm 25.2 \mathrm{a}$ & Yes \\
\hline AUS $\times$ ARG & $264.0 \pm 57.2 \mathrm{a}$ & $8.7 \pm 1.6 \#_{C}$ & $9(90.0)$ & $121.6 \pm 55.5 \mathrm{c}, \mathrm{e}$ & $43.8 \pm 15.1 \mathrm{a}, \mathrm{b}$ & $36.0 \pm 39.6 b$ & No \\
\hline$A R G \times A U S$ & $172.9 \pm 34.8 c$ & $9.0 \pm 1.5^{\#} \mathrm{C}$ & $24(100)$ & $83.3 \pm 23.5 \mathrm{c}, \mathrm{f}$ & $47.9 \pm 8.2 \mathrm{a}$ & $0.3 \pm 0.5 \mathrm{c}$ & $* *$ \\
\hline$\ldots$ ARG & $50.3 \pm 55.8 d$ & $15.3 \pm 3.8^{\# \mathrm{~b}, \mathrm{~d}}$ & $2(50)$ & $24.5 \pm 26.2 \mathrm{a}, \mathrm{b}, \mathrm{d}, \mathrm{f}$ & $24.0 \pm 12.2 \mathrm{a}, \mathrm{b}, \mathrm{c}$ & $0.5 \pm 0.7 \mathrm{c}$ & $* *$ \\
\hline$[\times$ AUS & $61.3 \pm 40.0 \mathrm{~d}$ & $16 . \pm 2.9 \# d$ & $15(65.3)$ & $11.8 \pm 7.4 \mathrm{~d}$ & $13.3 \pm 6.5 c$ & $0.1 \pm 0.3 c$ & $* *$ \\
\hline
\end{tabular}

+Each cross represented one independent infestation sleeve glued to the host dorsum.

* Values presented as mean \pm standard deviation.

\&Feeding period refers to days elapsed from larval infestation to detachment of engorged females.

\# Feeding period refers to days elapsed from adult infestation to detachment of engorged females.

EPE: egg production efficiency (weight of egg mass/weight of the engorged female $\times 100$ ).

@ Larvae generated from each cross were infested in a separate sleeve on a calf; fertility of the resulting engorged females was evaluated (see Table 4).

** Cross produced zero or a very low number of $\mathrm{F}_{1}$ larvae to perform an infestation.

Values followed by different letters in the same column are significantly different $(P<0.05)$.

\section{Phylogenetic analysis of tick mitochondrial I2S and I6S rDNA}

Specimens of sixteen strains of $R$. microplus from America, Africa, Asia and Oceania and one strain of each R. annulatus and $R$. decoloratus from Africa were used for DNA extraction and sequencing of mitochondrial $12 \mathrm{~S}$ and $16 \mathrm{~S}$ rDNA (Table 1). One to three specimens from each strain were analyzed. DNA was extracted from alcohol-preserved specimens and polymerase chain reaction (PCR) amplification of a fragment of the mitochondrial 16S rDNA was conducted as described [14]. The PCR conditions for 12S rDNA amplification were as described [15]. Amplified PCR products were purified using Wizard PCR Preps DNA Purification System (Promega Corporation, Madison, Wisconsin, USA). The purified DNA was directly sequenced at the IMyZA (Instituto de Microbiología y Zoología Agrícola, INTA, Castelar, Buenos Aires, Argentina). Both DNA strands were sequenced and assembled using BioEdit 7.05.3 software [16].

For phylogenetic analysis, the following tick mitochondrial $16 \mathrm{~S}$ and $12 \mathrm{~S}$ rDNA sequences available in the Genbank were also included:

\section{I6S rDNA}

R. annulatus, Spain (Z97877), R. annulatus, USA (L34311), R. microplus, USA (L34310), R. microplus, strain 9 from Taiwan (AY974232), Dermacentor andersoni, USA (L34299), D. marginatus, Spain (97879), D. variabilis, USA (L34300), Haemaphysalis juxtakochi, Uruguay (Y762323), H. leporispalustris, USA (L34309), H. punctata, Spain (Z97880), Hyalomma dromedarii, UK (L34306), H. lusitanicum, Spain (Z97881), Rhipicephalus appendiculatus, UK (L34301), R. bursa, Spain (97878), R. pusillus,

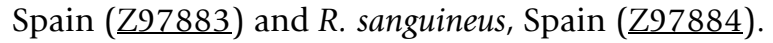

\section{I2S rDNA}

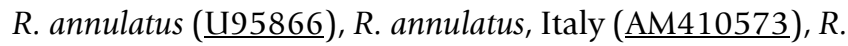
annulatus, Israel (AF133058), R. microplus, Nepal

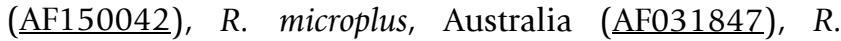
decoloratus, Zimbabwe (F150044), R. decoloratus, Kenya

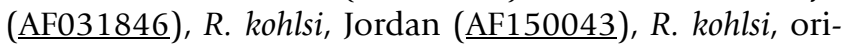
gin unknown (AY008686), Dermacentor albipictus, USA (AF150041), D. andersoni, USA ( $\underline{\text { AF150040) }}$, D. reticulatus, France (AF150038), Haemaphysalis leachi, Zimbabwe (AF150035), H. punctata, Switzerland (F150032), Hyalomma dromedarii, Morocco (AF150036), H. truncatum, Zimbabwe (AF150031), Rhipicephalus appendiculatus,

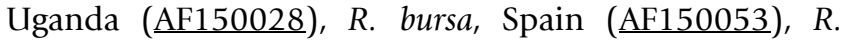
evertsi evertsi, Zimbabwe (F150052), R. pusillus, France (AF150022), R. sanguineus, France ( $\underline{\mathrm{AF} 150020})$, and $R$. turanicus, France (AF150018).

Multiple sequence alignments were done using Clustal W [17]. Phylogenetic and molecular evolutionary analyses were conducted using MEGA version 4 [18]. Phylogenetic relationships between sequences were assessed by neighbored-joining (NJ) method [19]. The NJ topologies were examined using Tamura-Nei distances [20] and relative support for the internal nodes was tested by bootstrapping over 1,000 replications [21]. Tamura-Nei distance measures were used because this model corrects for multiple hits, taking into account the differences in substitution rate between nucleotides and the inequality of nucleotide frequencies. It distinguishes between transitional substitution rates between purines and transversional substitution rates between pyrymidines. All positions containing alignment gaps were eliminated only in pairwise sequence comparisons. Ticks species of the genus Haemaphysalis were treated as out-group.

\section{Analysis of microsatellite polymorphism}

Microsatellite polymorphism was analyzed in tick strains from Argentina, Australia, Mozambique, India and New Caledonia (Table 1). For Argentina, Australia and Mozambique strains, female $e_{\text {strain } 1} \times$ male $_{\text {strain } 2}$ and female $e_{\text {strain } 2} \times$ male $_{\text {strain } 1}$ homologous and heterologous crosses were used. For each cross, egg masses from two separate crosses 
Table 3: Results of experiment II in which a calf was infested with crosses of adult ticks of Rhipicephalus (Boophilus) microplus strains from Australia (AUS), Argentina (ARG) and Mozambique (MOZ).

\begin{tabular}{|c|c|c|c|c|c|c|c|}
\hline $\begin{array}{c}\text { Cross }^{+} \\
(\text {male } \times \text { female) }\end{array}$ & $\begin{array}{l}\text { Engorged female } \\
\text { weight (mg)* }\end{array}$ & $\begin{array}{l}\text { Feeding period } \\
\text { (days)*\# }\end{array}$ & $\begin{array}{l}\text { No. engorged females } \\
\text { that oviposited (\%) }\end{array}$ & $\begin{array}{l}\text { Egg mass weight } \\
(\mathrm{mg})^{*}\end{array}$ & EPE* & $\%$ egg hatching* & F,fertility@ \\
\hline $\mathrm{MOZ} \times \mathrm{MOZ}$ & $252.3 \pm 81.1 \mathrm{a}$ & $7.6 \pm 0.6 \mathrm{a}, \mathrm{f}$ & $21(96.1)$ & 123.2. $\pm 60.0 \mathrm{a}, \mathrm{c}$ & $47.1 \pm 15.5 \mathrm{a}, \mathrm{c}, \mathrm{d}, \mathrm{e}$ & $85.5 \pm 30.4 a$ & Yes \\
\hline$A R G \times A R G$ & $257.4 \pm 65.6 \mathrm{a}$ & $6.5 \pm 0.8 b$ & $19(95.0)$ & $131.9 \pm 29.6 \mathrm{a}$ & $51.2 \pm 5.7 \mathrm{a}, \mathrm{c}$ & $85.3 \pm 28.3 \mathrm{a}$ & Yes \\
\hline AUS $\times$ AUS & $116.1 \pm 36.3 b$ & $7.4 \pm 1.5 \mathrm{a}, \mathrm{b}, \mathrm{d}$ & $14(100)$ & $39.9 \pm 17.9 \mathrm{~b}$ & $33.4 \pm 7.4 \mathrm{~b}$ & $20.9 \pm 28.0 b$ & Yes \\
\hline$M O Z \times A R G$ & $230.5 \pm 58.2 \mathrm{a}$ & $8.1 \pm 0.7 c, d, f$ & II (9I.7) & $122.5 \pm 36.2 \mathrm{a}, \mathrm{c}$ & $50.2 \pm 7.5 \mathrm{c}, \mathrm{d}$ & $85.0 \pm 31.7 \mathrm{a}$ & Yes \\
\hline MOZ $\times$ AUS & $100.4 \pm 32.4 b$ & $8.8 \pm 1.6 \mathrm{c}$ & $15(83.3)$ & $43.3 \pm 18.3 b$ & $39.9 \pm 6.9 \mathrm{e}$ & $0.0 \pm 0.0$ & $* *$ \\
\hline$A R G \times M O Z$ & $236.9 \pm 58.9 \mathrm{a}$ & $9.2 \pm 1.8 \mathrm{c}, \mathrm{e}$ & $18(100)$ & $122.6 \pm 38.2 \mathrm{a}, \mathrm{c}$ & $51.0 \pm 5.4 \mathrm{c}$ & $84.7 \pm 33.3 \mathrm{a}$ & Yes \\
\hline$A R G \times A U S$ & $117.8 \pm 31.4 b$ & $8.4 \pm 1.1 \mathrm{c}, \mathrm{d}$ & $10(90.9)$ & $55.6 \pm 19.1 \mathrm{~b}$ & $45.7 \pm 6.6 d$ & $0.0 \pm 0.0$ & ** \\
\hline AUS $\times$ MOZ & $226.2 . \pm 51.3 \mathrm{a}$ & $8.0 \pm 1.3 \mathrm{c}, \mathrm{f}$ & $24(100)$ & $103.9 \pm 12.4 c$ & $46.5 \pm 12.4 c, d$ & $53.6 \pm 40.4 c$ & No \\
\hline AUS $\times$ ARG & $233.0 \pm 56.6 \mathrm{a}$ & $7.0 \pm 1.6 \mathrm{a}, \mathrm{b}$ & $15(83.3)$ & $114.4 \pm 30.0$ a.c & $47.5 \pm 30.0 \mathrm{c}, \mathrm{d}$ & $15.6 \pm 21.5 b$ & No \\
\hline$\ldots \mathrm{MOZ}$ & $96.0 \pm 71.0 \mathrm{~b}, \mathrm{c}$ & $15.9 \pm 3.2 \mathrm{~g}$ & II (57.9) & $61.4 \pm 32.7 b$ & $40.8 \pm 13.9 b, d, e$ & $0.0 \pm 0.0$ & $* *$ \\
\hline$\times \mathrm{ARG}$ & $66.2 \pm 44.0 \mathrm{c}, \mathrm{d}$ & $14.5 \pm 3.3 \mathrm{~g}, \mathrm{~h}$ & $8(61.5)$ & $21.1 \pm 17.5 \mathrm{~d}$ & $22.4 \pm 9.9 f$ & $0.0 \pm 0.0$ & $* *$ \\
\hline$\times$ AUS & $52.9 \pm 19.1 \mathrm{~d}$ & $12.6 \pm 1.2 \mathrm{~h}$ & $7(70)$ & $8.3 \pm 3.4 \mathrm{~d}$ & $13.0 \pm 4.7 \mathrm{~g}$ & $0.0 \pm 0.0$ & $* *$ \\
\hline
\end{tabular}

+Each cross represented one independent infestation sleeve glued to the host dorsum.

* Values presented as mean \pm standard deviation.

\# Feeding period refers to days elapsed from adult infestation to detachment of engorged females.

EPE: egg production efficiency (weight of egg mass/weight of the engorged female $\times 100$ ).

@ Larvae generated from each cross were infested in a separate sleeve on a calf; fertility of the resulting engorged females was evaluated (see Table 4).

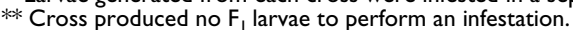

Values followed by different letters in the same column are significantly different $(P<0.05)$.

were used for genotyping. Tick DNA was obtained from egg batches (ARG, AUS and MOZ strains), pooled larvae (New Caledonia strain) or pooled whole ticks (India and Indonesia strains). Tick tissues were homogenized in liquid $\mathrm{N}$ or with a $1 \mathrm{ml}$ tuberculin syringe with a $25-\mathrm{G}$ needle to extract DNA with Tri Reagent (Sigma, St. Louis, MO, USA) following manufacturer's recommendations. The purified DNA was dissolved in distilled water and the concentration determined using the NanoDrop 1000 (Thermo Fisher Scientific, Wilmington, DE, USA).

Polymorphism was analyzed at microsatellite loci BmA12 (Genbank accession number DQ001904), BmA06
$(\underline{\mathrm{DQ} 001905}), \quad \mathrm{BmB12} \quad(\underline{\mathrm{DQ} 001906}), \quad$ BmC03 (DQ001907), BmC07 (DQ001909) and BmD12 (DQ001911) using oligonucleotide primers and PCR cycling conditions described [22]. The PCR was done with labeled forward primers (BmA12 and BmD12, 6-FAM; BmA06 and BmC07, NED; BmB12, VIC; BmC03, PET) in a $50-\mu$ l volume $\left(1.5 \mathrm{mM} \mathrm{MgSO}_{4}, 1 \mathrm{X}\right.$ avian myeloblastosis virus (AMV) RT/Thermus flavus (Tfl) reaction buffer, 0.2 $\mathrm{mM}$ each deoxynucleoside triphosphate (dNTP), $5 \mathrm{u} \mathrm{Tfl}$ DNA polymerase, $0.2 \mu \mathrm{M}$ of each oligonucleotide primer) employing the Access RT-PCR system (Promega, Madison, WI, USA). Reactions were performed in an automated DNA thermal cycler (Techne model TC-512, Cambridge,

Table 4: Results of infestation with larvae obtained from each fertile cross in experiments I (Table I) and II (Table 2) with Rhipicephalus (Boophilus) microplus strains from Australia (AUS), Argentina (ARG) and Mozambique (MOZ).

\begin{tabular}{|c|c|c|c|c|c|c|}
\hline $\begin{array}{l}\text { Experiment No. }- \text { Cross } \\
\text { (male } \times \text { female) that } \\
\text { generated the larvae used } \\
\text { for infestation }\end{array}$ & $\begin{array}{l}\text { Engorged female } \\
\text { weight (mg)* }\end{array}$ & $\begin{array}{l}\text { Feeding period } \\
\text { (days)*\# }\end{array}$ & $\begin{array}{l}\text { No. engorged } \\
\text { females that } \\
\text { oviposited (\%) }\end{array}$ & $\begin{array}{l}\text { Egg mass weight } \\
\qquad(\mathrm{mg})^{*}\end{array}$ & $\mathrm{EPE}^{*}$ & \% egg hatching* \\
\hline$I-A U S \times A U S$ & $169.4 \pm 37.3 \mathrm{a}$ & $20.2 \pm 0.4 \mathrm{a}$ & $21(70.0)$ & $50.3 \pm 20.9 \mathrm{a}$ & $29.5 \pm 11.2 \mathrm{a}$ & $96.4 \pm 11.0 \mathrm{a}$ \\
\hline$I-A U S \times$ AUS & $192.8 \pm 53.2 \mathrm{a}, \mathrm{f}$ & $20.2 \pm 0.4 \mathrm{a}, \mathrm{b}$ & $5(100)$ & $52.0 \pm 33.9 \mathrm{a}, \mathrm{b}$ & $25.5 \pm 10.8 \mathrm{a}, \mathrm{d}$ & $27.2 \pm 39.6 b$ \\
\hline$I I-A U S \times A U S$ & $179.0 \pm 19.7 \mathrm{~b}, \mathrm{~g}$ & $21.1 \pm 0.8 \mathrm{~d}, \mathrm{e}$ & 7 (87.5) & $78.6 \pm 18.7 b$ & $43.5 \pm 8.9 b$ & $27.3 \pm 37.2 b$ \\
\hline$I-A R G \times A R G$ & $278.7 \pm 37.2 c$ & $22.5 \pm 0.9 f$ & $30(100)$ & $140.7 \pm 24.3 c$ & $50.4 \pm 5.2 b, c$ & $95.8 \pm 11.1 \mathrm{a}, \mathrm{d}$ \\
\hline$I I-A R G \times A R G$ & $309.4 \pm 26.0 \mathrm{~d}$ & $24.6 \pm 1.1 \mathrm{~g}$ & $29(96.7)$ & $156.8 \pm 20.0 \mathrm{~d}$ & $50.8 \pm 5.2 b, c$ & $84.2 \pm 28.3 c, d$ \\
\hline $\mathrm{II}-\mathrm{MOZ} \times \mathrm{MOZ}$ & $374.1 \pm 35.9 \mathrm{e}$ & $24.1 \pm 1.3 c$ & $28(93.3)$ & $183.3 \pm 34.6 \mathrm{e}$ & $49.2 \pm 9.4 b, c$ & $78.8 \pm 24.3 c$ \\
\hline $1-A U S \times A R G$ & $214.0 \pm 55.4 \mathrm{f}, \mathrm{g}$ & $20.6 \pm 0.6$ b.d & $29(96.7)$ & $74.2 \pm 25.3 b$ & $33.2 \pm 17.7 \mathrm{a}$ & $0.0 \pm 0.0$ \\
\hline$I-A U S \times A R G$ & $257.6 \pm 37.6 b$ & $21.1 \pm 1.3 \mathrm{e}$ & $30(100)$ & $62.0 \pm 28.4 \mathrm{a}, \mathrm{b}$ & $24.4 \pm 11.3 \mathrm{a}, \mathrm{d}$ & $0.0 \pm 0.0$ \\
\hline$I I-A U S \times A R G$ & $311.7 \pm 29.1 b$ & $21.0 \pm 1.1 \mathrm{e}$ & $30(100)$ & $163.7 \pm 24.5 \mathrm{~d}, \mathrm{f}$ & $52.4 \pm 4.7 \mathrm{c}, \mathrm{e}$ & $0.0 \pm 0.0$ \\
\hline$I I-A U S \times M O Z$ & $304.0 \pm 36.4 \mathrm{a}$ & $20.1 \pm 1.0 \mathrm{a}$ & $30(100)$ & $66.3 \pm 35.0 \mathrm{a}, \mathrm{b}$ & $22.3 \pm 12.1 \mathrm{~d}$ & $0.0 \pm 0.0$ \\
\hline$I I-M O Z \times A R G$ & $265.1 \pm 58.8 \mathrm{e}$ & $24.0 \pm 1.2 c$ & $30(100)$ & $147.3 \pm 38.6 \mathrm{c,d}$ & $55.6 \pm 10.3 \mathrm{e}, \mathrm{f}$ & $95.0 \pm 17.6 \mathrm{a}, \mathrm{d}$ \\
\hline II $-A R G \times M O Z$ & $299.7 \pm 57.8 \mathrm{~h}$ & $23.6 \pm 1.3 \mathrm{~h}$ & $29(97.7)$ & $179.6 \pm 44 . \mid$ e,f & $58.7 \pm 6.7 \mathrm{f}$ & $92.2 \pm 14.7 \mathrm{a}, \mathrm{c}$ \\
\hline
\end{tabular}

* Values presented as mean \pm standard deviation.

\# Feeding period refers to days elapsed from larval infestation to detachment of engorged females.

EPE: egg production efficiency (weight of egg mass/weight of the engorged female $\times 100$ ).

Values followed by different letters in the same column are significantly different $(P<0.05)$. 


\begin{tabular}{llllllllllllllllllllllllll}
\hline OTUs & 1 & 2 & 3 & 4 & 5 & 6 & 7 & 8 & 9 & 10 & 11 & 12 & 13 & 14 & 15 & 16 & 17 & 18 & 19 & 20 & 21 & 22 \\
\hline
\end{tabular}

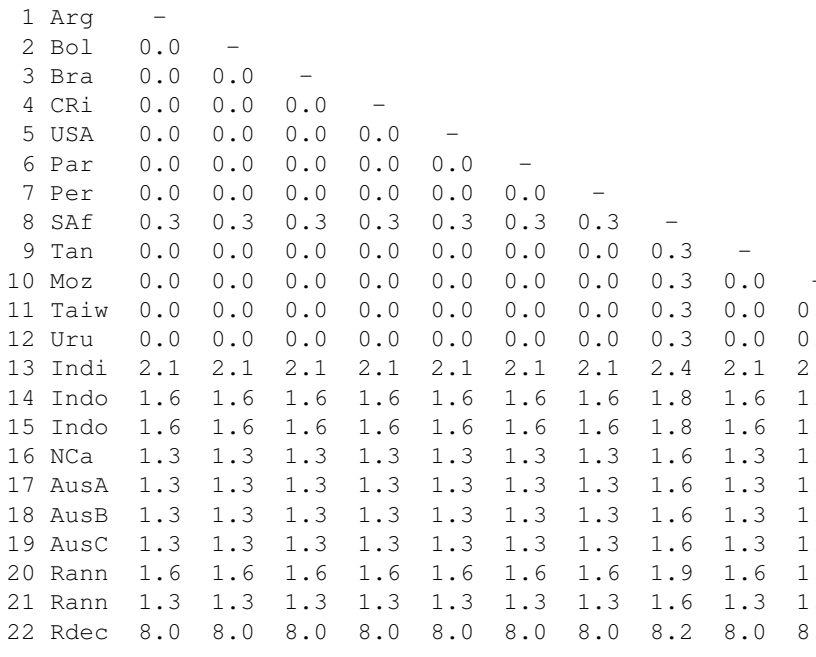

\section{Figure I}

Matrix of sequence differences on pairwise comparisons of the mitochondrial I6S rDNA gene for I9 R. microplus strains, $\boldsymbol{R}$. annulatus and $\boldsymbol{R}$. decoloratus. Proportion of nucleotide differences $\left(10^{2}\right)(p$-distance) are shown in the lower left matrix. It is obtained by dividing the number of nucleotide differences by the total number of nucleotides compared. (OTUs Operational taxonomic units, I Argentina, 2 Bolivia, 3 Brazil, 4 Costa Rica, 5 USA L343 I 0, 6 Paraguay, 7 Peru, 8 South Africa, 9 Tanzania, I0 Mozambique, II Taiwan AY974232, I2 Uruguay, I 3 India, I4 Indonesia I, I5 Indonesia 2 , I6 New Caledonia, I7 Australia A, I8 Australia B, 19 Australia C, 20 R. annulatus Z97877, 2 I R. annulatus L343I I, 22 R. decoloratus).

England, UK). The reaction was terminated after a final extension at $68^{\circ} \mathrm{C}$ for $5 \mathrm{~min}$. Control reactions were done using the same procedures, but without DNA added to check contamination of the PCR reaction. PCR products were electrophoresed on $1 \%$ agarose gels to check the size of amplified fragments by comparison to a DNA molecular weight marker (1 Kb Plus DNA Ladder, Promega). Fragments were separated using an ABI 3730 automated DNA sequencer (Applied Biosystems, Inc. Foster City, CA, USA) and sized relative to a ROX-labeled internal size standard (GeneScan-500LIZ, Applera, Norwalk, CT, USA). The data were analyzed using program Peak Scanner (Applied Biosystems).

For statistical analysis, a binary matrix was constructed by scoring the different alleles from each microsatellite locus as presence (1) and absence (0) of the PCR bands for each cross. Based on the binary matrix, similarity matrixes were calculated using Jaccard's and Dice's coefficients [23,24]. The similarity matrix was subjected to Sequential Agglomerative Hieratical Nested Clustering (SAHN) and dendograms were constructed employing the Unweighted Pair Group Method of Arithmetic Averages (UPGMA) of Sneath and Sokal [25] to group the progenies into clus- ters. All the analyses were performed using statistical software package NTSYSpc version 2.01e [26].

\section{Results \\ The crosses between Australia and Argentina or Mozambique strains are infertile}

Tick crosses were conducted between AUS, MOZ and ARG R. microplus strains (Tables 2 and 3). Both homologous and heterologous crosses of ARG and MOZ produced fertile offspring. AUS ticks produced a viable, fertile offspring in homologous crosses. However, AUS females failed to yield viable larvae in heterologous crosses. Even though heterologous crosses of AUS males with ARG or $\mathrm{MOZ}$ females produced viable offspring (mean egg hatching varying from $15.6 \%$ to $53.6 \%$ ), the resultant $F_{1}$ hybrid ticks were infertile in all cases (Table 4). In contrast, $\mathrm{F}_{1}$ ticks from heterologous crosses between ARG and MOZ were as fertile as the $F_{1}$ ticks from homologous crosses. This result suggested a lack of genetic compatibility between Australian ticks and strains from Africa and America. It was interesting to note the lower weight and feeding period of engorged AUS females, even in homologous crosses (Tables 2 and 4). Regardless of being fertile or not, females from all crosses were significantly heavier 


\begin{tabular}{llllllllllllllllllllllllllllllllllll}
\hline OTUs & 1 & 2 & 3 & 4 & 5 & 6 & 7 & 8 & 9 & 10 & 11 & 12 & 13 & 14 & 15 & 16 & 17 & 18 & 19 & 20 & 21 & 22 & 23 & 24 & 25 & 26 & \\
\hline
\end{tabular}

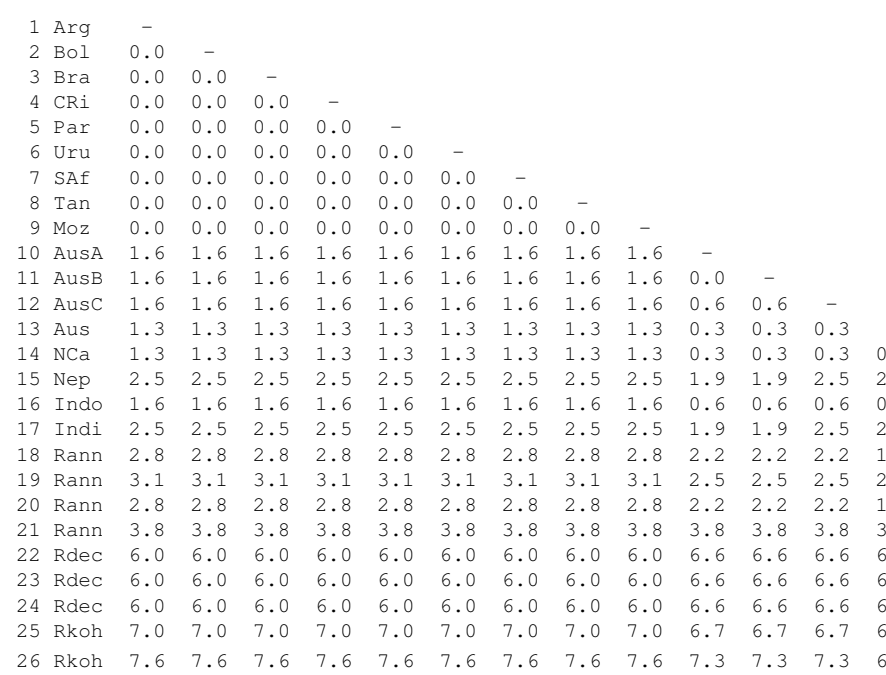

\section{Figure 2}

Matrix of sequence differences on pairwise comparisons of the mitochondrial I 2S rDNA gene for I 7 R. microplus strains, $\boldsymbol{R}$. annulatus, $\boldsymbol{R}$. decoloratus and $\boldsymbol{R}$. kohlsi. Proportion of nucleotide differences $\left(10^{2}\right)(p$-distance) are shown in the lower left matrix. It is obtained by dividing the number of nucleotide differences by the total number of nucleotides compared. (OTUs Operational taxonomic units, I Argentina, 2 Bolivia, 3 Brazil, 4 Costa Rica, 5 Paraguay, 6 Uruguay, 7 South Africa, 8 Tanzania, 9 Mozambique, 10 Australia A, II Australia B, I2 Australia C, I3 Australia AF03 I847, I4 New Caledonia, I 5 Nepal AFI50042, I6 Indonesia, I7 India, I8 R. annulatus Egypt, I9 R. annulatus AM4I0573, 20 R. annulatus AFI33058, 21 R. annulatus U95866, 22 R. decoloratus South Africa, 23 R. decoloratus AFI50044, 24 R. decoloratus AF03I846, 25 R. kohlsi AY008686, 26 R. kohlsi AFI50043).

and showed feeding periods significantly shorter than their corresponding virgin female controls.

\section{The Australian tick strain is genetically more divergent than Asian, African and American strains}

Approximately $400 \mathrm{bp}$ of the mitochondrial 16S rDNA gene were successfully sequenced from specimens of $R$. microplus representing 16 different strains from America, Africa, Asia and Oceania. The analysis of 16S rDNA sequences variation revealed very little genetic diversity ( 0.0 to $0.3 \%$ ) between American and African strains (Fig. $1)$. In contrast, genetic diversity at this locus was $1.3-1.6 \%$ and $1.6-2.4 \%$ when these strains were compared to $R$. microplus from Oceania and Asia, respectively (Fig. 1). For 12S rDNA, approximately 350 bp were sequenced from $R$. microplus representing 15 strains from America, Africa, Asia and Oceania. No differences were observed in $12 \mathrm{~S}$ rDNA sequences between American and African strains (Fig. 2). However, when these strains were compared to $R$. microplus from Oceania and Asia, the genetic diversity was $1.3-1.6 \%$, and $1.6-2.5 \%$, respectively.

The phylogenetic analysis of $16 \mathrm{~S}$ sequences showed that sequences of $R$. microplus from America form a clade with
African strains and the Taiwan (AY974232) sequence (98\% bootstrap support) whereas the strains from Australia, New Caledonia and Indonesia grouped together in a different cluster (Fig. 3). Surprisingly, sequences of $R$. annulatus from USA and Spain formed a third cluster with R. microplus from India with a relatively high bootstrap support (76\%) (Fig. 3). The phylogenetic analysis of $12 \mathrm{~S}$ rDNA sequences was similar to the analysis of $16 \mathrm{~S}$ rDNA (Fig. 4). This analysis provided strong support for a clade including R. microplus from America and Africa (98\% bootstrap support). The strains from Australia, New Caledonia and Indonesia formed another cluster with a relatively high bootstrap support (78\%). Finally, a strong support (99\%) was found for a third clade containing $R$. microplus from India and Nepal (AF150043). In this analysis, the $R$. annulatus $12 \mathrm{~S}$ rDNA sequences grouped in a separate cluster with a low bootstrap support (65\%).

The analysis of microsatellite loci was conducted to provide additional evidences of genetic polymorphism between tick strains using nuclear genome markers. In these experiments, egg masses from two separate homologous and heterologous crosses were used and allele number and size was determined for each locus (Table 5 


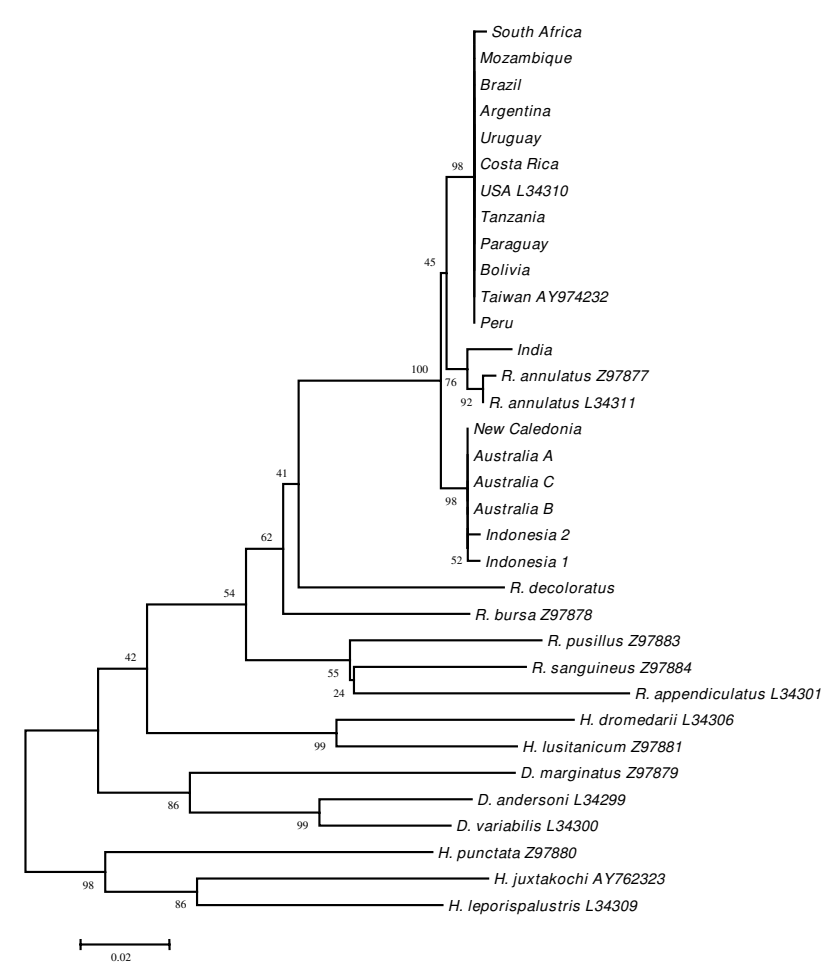

Figure 3

Neighbor-Joining tree of the I6S rDNA sequences using the Tamura-Nei method. The percentage of replicate trees in which the associated taxa clustered together in the bootstrap test ( 1000 replicates) is shown next to the branches. The tree is drawn to scale with branch lengths in the same units as those of the evolutionary distances used to infer the phylogenetic tree.

and Additional file 1). The UPGMA clustering analysis of microsatellite alleles obtained in the progenies of $R$. microplus crosses showed that homologous and heterologous crosses involving AUS had lower similarity coefficients when compared to other homologous and heterologous crosses between MOZ and ARG strains (Fig. $5 \mathrm{~A}$ and $5 \mathrm{~B}$ ). Some microsatellite loci did not provide a clear genotype for the $\mathrm{MOZ} \times \mathrm{MOZ}$ cross and in ticks from India and New Caledonia (Additional file 1), probably due to the presence of null alleles in these strains.

\section{Discussion}

This paper introduced a combined approach based on biological and molecular tools to provide additional support for the hypothesis of the existence of at least two different tick species currently considered as $R$. microplus. The most important evidences were provided by studies of crosses between tick strains which showed reproductive isolation of the Australian strain. Genetic analyses of mitochondrial and nuclear genome markers were not conclusive but provided support for the genetic diver-

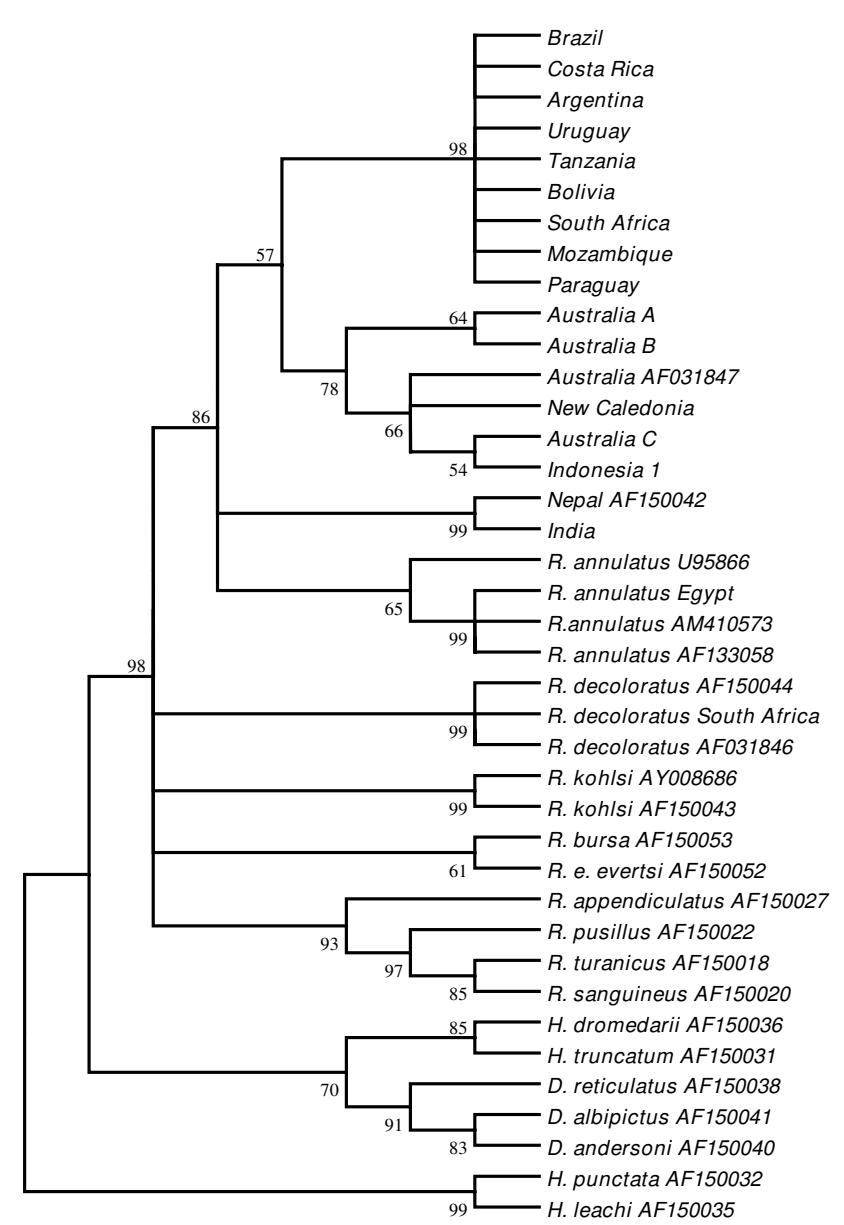

Figure 4

Condensed Neighbor-Joining tree of the I 25 rDNA sequences using the Tamura-Nei method. The interior branches with less than $50 \%$ bootstrap support were collapsed. Numbers next to the branches represent the percentages of bootstrap values (1000 replicates).

gence between the Australian and African/American strains.

Previous results have suggested that the Australian strains of $R$. microplus show biological differences when compared to other R. microplus strains from Africa and America [7]. In these studies, sterile progenies were obtained from crosses between strains from Australia and South Africa. In addition, the mean number of eggs produced by engorged females of American strains is higher than that obtained from Australian strains [27-30]. Furthermore, the amount of the insect growth regulator fluazuron required for complete growth inhibition in Australian tick strains is lower than that required for the Argentinean strains [31]. These results suggested that Australian $R$. microplus differ from strains in America and Africa and may have evolved into a separate species. 
Table 5: Genotyping of microsatellite loci in geographic strains of $R$. microplus.

\begin{tabular}{|c|c|c|c|c|c|c|c|c|c|c|c|c|}
\hline \multirow{3}{*}{$\begin{array}{l}\text { Tick } \\
\text { strains }^{\mathbf{a}}\end{array}$} & \multicolumn{12}{|c|}{ Microsatellite loci (repeated array) } \\
\hline & $\underset{(\mathrm{CA})_{3+7}(\mathrm{CG})_{4}}{\mathbf{B m A l 2}}$ & & $\begin{array}{c}\text { BmA06 } \\
(\mathrm{GT})_{8+2}\end{array}$ & & $\begin{array}{c}\text { BmB I 2 } \\
(\mathrm{TA})_{4}(\mathrm{TG})_{9}\end{array}$ & & $\begin{array}{l}\mathrm{BmCO3} \\
(\mathrm{CA})_{10+9}\end{array}$ & & $\underset{(\mathrm{GT})_{17}}{\mathrm{BmC07}}$ & & $\begin{array}{l}\text { BmD I } 2 \\
(\mathrm{CA})_{10+5}\end{array}$ & \\
\hline & $\mathrm{Na}$ & SR (bp) & $\mathrm{Na}$ & SR (bp) & $\mathrm{Na}$ & SR (bp) & $\mathrm{Na}$ & SR (bp) & $\mathrm{Na}$ & SR (bp) & $\mathrm{Na}$ & SR (bp) \\
\hline $\begin{array}{l}\text { MOZ } \times \\
\text { MOZ }\end{array}$ & 1 & 94 & ND & ND & 3 & [180-216] & 5 & [157-17I] & 4 & [132-192] & 2 & {$[93 ; 95]$} \\
\hline $\begin{array}{l}\text { ARG } \times \\
\text { ARG }\end{array}$ & 1 & 94 & 2 & [99; I0I] & 5 & [180-216] & 2 & {$[173 ; 175]$} & I & 144 & 1 & 93 \\
\hline $\begin{array}{l}\text { AUS } \times \\
\text { AUS }\end{array}$ & 4 & [94-200] & 4 & {$[96-102]$} & 4 & [191-199] & 4 & [146-158] & 3 & [144-180] & 4 & [88-105] \\
\hline $\begin{array}{l}\text { MOZ } \times \\
\text { ARG }\end{array}$ & 1 & 94 & 2 & [99; 10I] & 4 & {$[180-2 \mid 6]$} & 6 & [165-175] & 5 & [132-192] & 5 & [93-109] \\
\hline $\begin{array}{l}\text { AUS } \times \\
\text { ARG }\end{array}$ & 4 & [94-200] & 5 & [96-10I] & 6 & {$[|86-2| 4]$} & 5 & [146-175] & 5 & [132-150] & 8 & {$[88-1 \mid 2]$} \\
\hline $\begin{array}{l}\text { AUS } x \\
\text { MOZ }\end{array}$ & 3 & [94-198] & 3 & [98-102] & 4 & [180-199] & 6 & [157-17I] & 8 & [144-192] & 4 & [88-109] \\
\hline India & 3 & [198-218] & 2 & {$[108 ; 204]$} & 1 & 180 & ND & ND & ND & ND & ND & ND \\
\hline $\begin{array}{l}\text { New } \\
\text { Caledonia }\end{array}$ & 1 & 200 & 1 & 108 & 4 & {$[176-199]$} & ND & ND & 2 & {$[146 ; 150]$} & 1 & 107 \\
\hline
\end{tabular}

aFor Argentinean (ARG), Australian (AUS) and Mozambican (MOZ) strains, egg masses from two separate crosses were used for DNA extraction and genotyping following

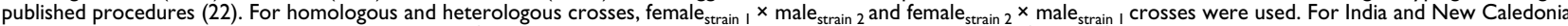
strains, pooled tick larvae and adult ticks were used for analysis, respectively. ND, not determined; Na, number of alleles; SR, allele size range.

To test this hypothesis, we conducted experiments to characterize the reproductive performance and genetic diversity of $R$. microplus strains from Australia, Africa and America. The results clearly showed that tick strains from Africa (Mozambique) and America (Argentina) have no biological barrier for reproduction, being therefore the same species. All the reproductive parameters were significantly reduced when the Australian strain was involved in heterologous crosses suggesting the existence of a separate species. The genetic analysis of mitochondrial $12 \mathrm{~S}$ and $16 \mathrm{~S}$ rDNA as well as nuclear microsatellite loci sequences further suggested that strains from Africa and South America are conspecific. According to these analyses, ticks from Australia, Indonesia and New Caledonia would be also conspecific, different from the American-African strains. While clustered in a different clade, support for a separate species in India and Nepal was inconclusive. Interestingly, the results of the microsatellite analysis suggested the absence of transmission ratio distortion between paternal and maternal alleles even in the offspring of the AUS crosses with either ARG and/or MOZ strains, reducing the possibility of parental genetic effects to explain strain incompatibility.

It is well known that in the absence of males, Metastriata females increase their feeding period, have smaller repletion weights and oviposit none or only few fertile eggs when compared to females mated with conspecific males [32]. In the present study, females from all crosses showed feeding periods significantly shorter and significantly higher repletion weights than the virgin female controls. This result indicated that all crosses resulted in copula regardless of being fertile or not and evidenced that AUS females were attractive to ARG and MOZ males and vice versa. Attractiveness and cross-mating between $R$. microplus and $R$. annulatus has been reported, resulting in sterile hybrids [33], similarly to our results for heterologous crosses with AUS ticks.

One possible drawback of this study is the use of the Australian Yeerongpilly strain, which has been kept in the laboratory for over 60 years [34]. This strain has been also used in previous analyses of the reproductive success of heterologous crosses [7]. However, while low reproductive performance could be ascribed to continuous maintenance of the strain in the laboratory, differences were not observed in $12 \mathrm{~S}$ and $16 \mathrm{~S}$ rDNA sequences between the Yeerongpilly strain, the other two Australian strains analyzed in this study (A and B; Tables 4 and 5) and those reported by Murrell et al. [35]. Therefore, reproductive isolation seems to be a factual character associated to the strain and not a side effect of long-term laboratory maintenance.

Although mitochondrial 12S and 16S rDNA phylogenies were constructed with sequences from multiple Australian strains, the studies of the reproductive performance and microsatellite polymorphism were conducted with a single Australian (Yeerongpilly) strain, a fact that should be taken with caution when generalizing these results to Australian R. microplus in general. However, despite the limitations of the study, the results reported herein support the hypothesis that at least two species exist under the name $R$. microplus. These species could be redefined as $R$. 
A

UPGMA clustering analysis

Jaccard coefficient

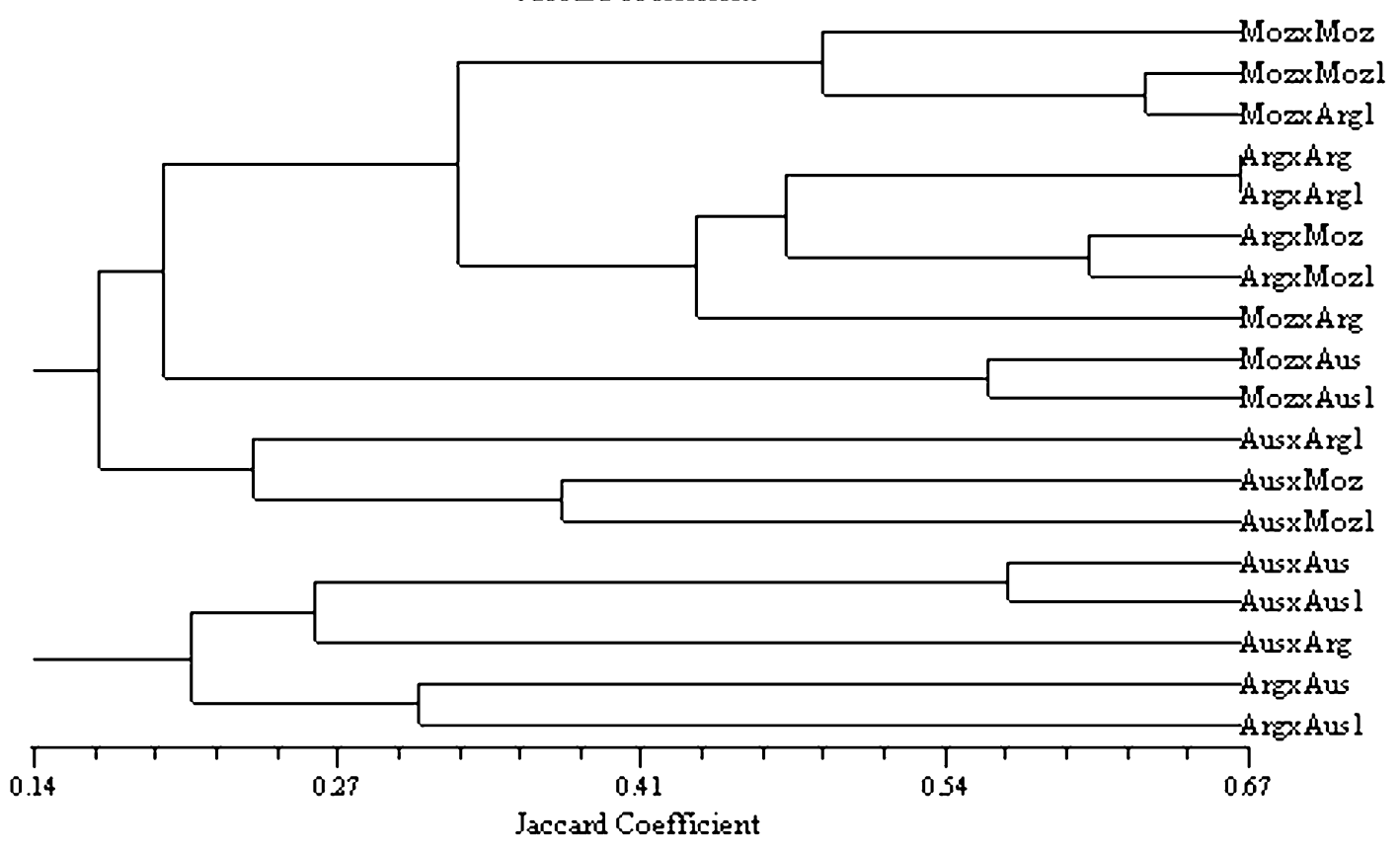

B

UPGMA clustering analysis

Dice coefficient

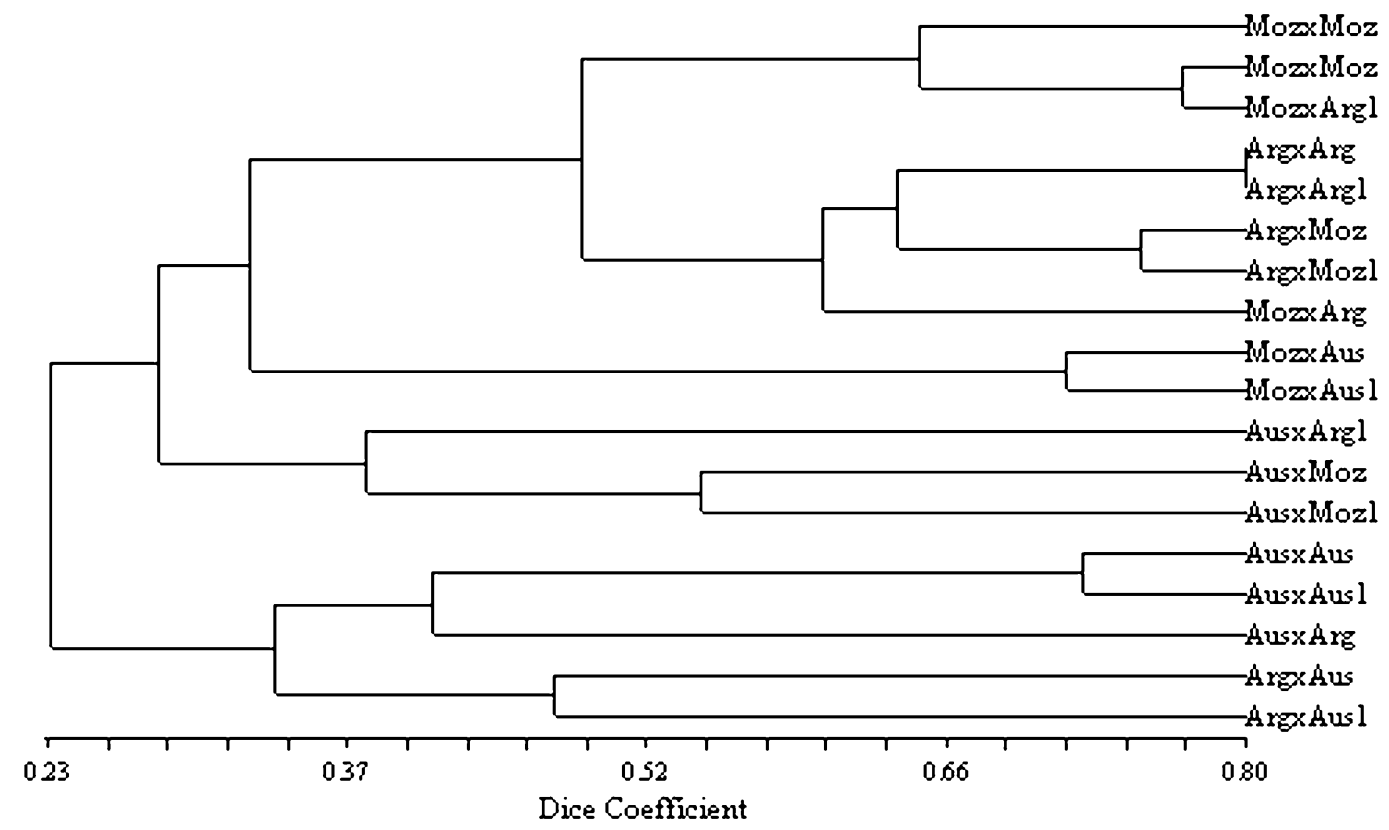

Figure 5

UPGMA clustering analysis of microsatellite alleles obtained in the progenies of homologous and heterologous crosses of $\boldsymbol{R}$. microplus tick strains from different geographic locations. For homologous and heterologous crosses,

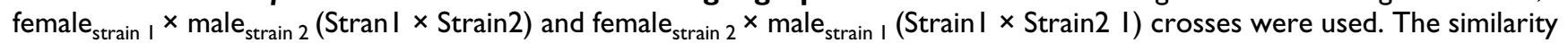
matrixes were obtained using (A) Jaccard's and (B) Dice's coefficients and the similarity values are shown in the $X$-axis. Both dendograms show the same topology. 
microplus (Canestrini, 1887) (for American and African strains) and probably R. australis Fuller, 1899 (for Australian strains). After its description, $R$. australis was reported in Africa. However, these records were synonymized under $R$. annulatus. Interestingly, $R$. annulatus appeared within the monophyletic clade of $R$. microplus in the $16 \mathrm{~S}$ mtDNA tree or as a paraphyletic branche in the $12 \mathrm{~S}$ mtDNA tree suggesting that the denomination of $R$. annulatus may needs revision. Currently, $R$. australis is regarded as a synonym of $R$. microplus. Biological features reported here, including the lack of fertile $\mathrm{F}_{1}$ progeny in heterologous crosses and smaller, significantly different weight of engorged Australian (Yeerongpilly strain) females as well as molecular findings involving different Australian strains are clearly supportive of the hypothesis of a reproductive isolation between Australian and American/African ticks. We can not ascribe the Australian-IndonesianCaledonian specimens to that species until the finding of its types and further morphological comparisons are conducted. It is also possible that other boophilid tick strains may inhabit small areas of the South Pacific. This issue warrants further studies by conducting detailed morphologic, genetic and reproductive studies with multiple tick strains collected at different geographic locations and cured from their endosymbionts which may affect tick reproductive performance.

It is important to note that the introduction of $R$. microplus into Africa took place with animals from India, after the epidemic of Rinderpest in the 19th century. Although it is hypothesized that $R$. microplus entered into South America along with Indian cattle, information is currently not available to support this hypothesis. However, the introduction of $R$. microplus in Australia took place with animals from Indonesia (most probably cattle from Java around 1870) [36] and then later into New Caledonia with Australian cattle (Barré, pers. comm.). This fact is in agreement with the reproductive and molecular findings of this study: ticks from Indonesia, Australia and New Caledonia may be a different, reproductively isolated species. As mentioned before, the strains from India and Nepal may constitute a different species, closer to African and American $R$. microplus, but adequate biological evidence is lacking and molecular evidence presented herein are not conclusive and/or may be the result of allopatric evolution. Detailed morphological, genetic and reproductive studies of tick strains from Africa, America, Australia, Indonesia, New Caledonia, India and Nepal would be necessary before confirming the redescription and possible resurrection of other boophilid tick species. Nevertheless, until further studies are conducted, caution should be taken in extrapolating results from studies on Australian ticks determined as $R$. microplus. These data have important implications in the field of animal health, because many studies involving ecology and control of cattle ticks performed on Australian tick strains considered as R. microplus may not be directly applicable to tick strains in America or Africa.

\section{Conclusion}

The results reported herein provided biological and genetic evidences of allopatric speciation in $R$. microplus and suggested a reproductive isolation for AustralianIndonesian-Caledonian strains resulting in a different species. These results support the hypothesis that at least two different species have evolved under the name $R$. microplus. These species must be redefined after careful inspection of type specimens and further analysis of local tick fauna, including studies with several tick strains from each geographic location.

\section{Authors' contributions}

MBL conducted the tick crosses. MBL and AE-P analyzed the results of tick crosses. VN and AJM obtained new tick sequences. AJM and AAG conducted phylogenetic analyses. VN, CT and JF obtained and analyzed tick microsatellites. MBL, AE-P, AAG, FJ and JF conceived and participated in study design. MBL, AE-P, AAG, AJM, FJ and JF helped to draft the manuscript. All authors read and approved the final manuscript.

\section{Additional material}

\section{Additional file 1}

Microsatellite genotypes of individual crosses. The data provided represent the microsatellite alleles identified in all tick crosses.

Click here for file

[http://www.biomedcentral.com/content/supplementary/14712148-9-46-S1.xls]

\section{Acknowledgements}

We thank Peter Willadsen (CSIRO Livestock Industries, Queensland, Australia) for the information about the Yeerongpilly tick strain, Martín N. García (Intituto de Recursos Naturales, INTA, Castelar, Argentina) for technical assistance and Wilson R. Fernandes (Faculty of Veterinary, University of São Paulo) for logistic support for tick infestations on cattle. S. Ghosh (Entomology Laboratory, Division of Parasitology, Indian Veterinary Research Institute, Izatnagar, India) is acknowledged for supplying the Indian tick strain. Members of the Integrated Consortium on Ticks and Tick-borne Diseases (ICTTD-3) are acknowledged for fruitful discussions and suggestions. This work was supported by ICTTD-3, financed by the International Cooperation Program of the European Union, coordination action project No. 51056I, the Consejería de Educación y Ciencia, JCCM, Spain (project PAI06-0046-5285) (to JF), the Conselho Nacional de Desenvolvimento Científico e Tecnológico - CNPq (to MBL), the Consejo Nacional de Investigaciones Cientícas y Técnicas de Argentina (PIP 2058) and INTA Rafaela (TCP 426100) (to AJM, AAG and CT). V. Naranjo was funded by Junta de Comunidades de Castilla - La Mancha (JCCM), Spain. 


\section{References}

I. Estrada-Peña A, Bouattour A, Camicas JL, Guglielmone A, Horak Jongejan F, Latif A, Pegram R, Walker AR: The known distribution and ecological preferences of the tick subgenus Boophilus (Acari: Ixodidae) in Africa and Latin America. Exp Appl Acarol 2006, 38:219-235.

2. Peter RJ, Bossche P Van den, Penzhorn BL, Sharp B: Tick, fly, and mosquito control-Lessons from the past, solutions for the future. Vet Parasitol 2005, I 32:205-2 I5.

3. de la Fuente J, Estrada-Peña A, Venzal JM, Kocan KM, Sonenshine DE: Overview: Ticks as vectors of pathogens that cause disease in humans and animals. Frontiers in Biosciences 2008, 1 3:6938-6946.

4. García-García JC, González IL, González DM, Valdés M, Méndez L, Lamberti J, D'Agostino B, Citroni D, Fragoso H, Ortiz M, Rodríguez $M$, de la Fuente J: Sequence variations in the Boophilus microplus Bm86 locus and implications for immunoprotection in cattle vaccinated with this antigen. Exp Appl Acarol 1999, 23:883-895.

5. de la Fuente J, García-García JC, González DM, Izquierdo G, Ochagavia ME: Molecular analysis of Boophilus spp. (Acari: Ixodidae) tick strains. Vet Parasitol 2000, 92:209-222.

6. Londt JGH, Arthur D: The structure and parasitic life cycle of Boophilus microplus (Canestrini, 1888) in South Africa (Acarina: Ixodidae). J Entomol Soc S Afr 1975, 38:32 I-340.

7. Spickett AM, Malan AR: Genetic incompatibility between Boophilus decoloratus (Koch 1844) and Boophilus microplus (Canestrini, I888) and hybrid sterility of Australian and South African Boophilus microplus (Acarina: Ixodidae). Onderstepoort J Vet Res 1978, 45:|49-|53.

8. Guglielmone AA, Estrada-Peña A, Keirans JE, Robbins RG: Ticks (Acari: Ixodidae) of the Neotropical Zoogeographic Region. Special Publication, International Consortium on Ticks and Tickborne Diseases, Atalanta, Houten, The Netherlands; 2003:I73.

9. Barker SC: Distinguishing species and strains of Rhipicephaline ticks with ITS2 ribosomal RNA. J Parasitol 1998, 84:887-892.

10. Baxter GD, Barker SC: Comparison of acetylcholinesterase genes from cattle ticks. Int J Parasitol 1999, 29:।765-I774.

II. Nava S, Guglielmone AA, Mangold AJ: An overview of systematic and evolution of ticks. Front Biosciences 2009, 14:3012-3023.

12. Drummond RO, Ernst SE, Trevino JL, Gladney WJ, Graham OH: Boophilus annulatus and B. microplus : laboratory tests of insecticides. J Econ Entomol 1973, 66:130-133.

13. Bennett GF: Oviposition of Boophilus microplus (Canestrini) (Acarina: Ixodidae). Acarologia 1974, I6: I652-I66I.

14. Mangold A], Bargues MD, Mas-Coma S: Mitochondrial I6S rDNA sequences and phylogenetic relationships of species of Rhipicephalus and other tick genera among Metastriata (Acari: Ixodidae). Parasitol Res 1998, 84:478-484

15. Szabó MPJ, Mangold AJ, Joao CF, Bechara GH, Guglielmone AA: Biological and DNA evidence of two dissimilar populations of the Rhipicephalus sanguineus tick group (Acari: Ixodidae) in South America. Vet Parasitol 2005, 130:131-140.

16. Hall TA: BioEdit: a user-friendly biological sequence alignment editor and analysis program for Windows 95/98/NT. Nucl Acids Symp 1999, 41 1:95-98.

17. Thompson JD, Higgins DG, Gibson TJ: Improving the sensitivity of progressive multiple sequence alignment through sequence weighting, position-specific gap penalties and weight matrix choice. Nucl Acids Res 1994, 22:4673-4680.

18. Tamura K, Dudley J, Nei M, Kumar S: MEGA4: Molecular Evolutionary Genetics Analysis (MEGA) software version 4.0. Mol Biol Evol 2007, 24: I596-1599.

19. Saitou N, Nei M: The neighbor-joining method: A new method for reconstructing phylogenetic trees. Mol Biol Evol 1987, 4:406-425

20. Tamura K, Nei M: Estimation of the number of nucleotide substitutions in the control region of mitochondrial DNA in humans and chimpanzees. Mol Biol Evol 1993, 10:5 I 2-526.

21. Felsenstein J: Confidence limits on phylogenies: An approach using the bootstrap. Evolution 1985, 39:783-79I.

22. Koffi BB, Risterucci AM, Joulia D, Durand P, Barré N, de Meeús T, Chevillon C: Characterization of polymorphic microsatellite loci within a young Boophilus microplus metapopulation. Mol Ecol Notes 2006, 6:502-504.
23. Jaccard P: Nouvelles recherches sur la distribution florale. Bull Soc Vaud Sci Nat 1908, 44:223-270.

24. Dice LR: Measures of the amount of ecologic association between species. Ecology 1945, 26:297-302.

25. Sneath PHA, Sokal RR: Numerical taxonomy: the principles and practice of numerical classification. W.H. Freeman \& Co., San Francisco; 1973:573.

26. Rohlf FJ: Adaptive hierarchical clustering schemes. Systematic Zool 1970, 19:58-82.

27. Legg J: Some observations on the life history of the cattle tick (Boophilus australis). Proc Roy Soc Queensland 1930, 4 I: I 21-132.

28. Hitchcock LF: Studies on the parasitic stages of the cattle tick Boophilus microplus. Can Aust J Zool 1954, 3: I45-I 55.

29. Alvarado RU, González JC: A postura e a viabilidade do Boophilus microplus (Canestrini, I 888) (Acarina, Ixodidae) en condicioes de laboratorio. Rev Lat Amer Microbiol 1979, 2 I:3 I-36.

30. Guglielmone AA, Mangold AJ, Aguirre DH, Gaído AB, Olsen AA: The effect of infection by Babesia sp. on some biological parameters of engorged females of Boophilus microplus. Folia Parasitol 1989, 36: |-6.

31. Guglielmone AA, Volpogni MM, Anziani OS, Hereu C: Evaluación del fluazuron (Acatak) para el control de poblaciones naturales de Boophilus microplus (Acari: Ixodidae) en Santiago del Estero, Argentina. Vet Arg 1998, I5:710-714.

32. Oliver JH Jr: Biology and systematics of ticks (Acari: Ixodida). Ann Rev Ecol Syst 1989, 20:397-430.

33. Graham OH, Price MA, Trevino JL: Cross-mating experiments with Boophilus annulatus and B. microplus (Acarina: Ixodidae). J Med Entomol 1972, 9:531-537.

34. Hitchcock LF, Roulston WJ: Arsenic resistance in a strain of cattle tick (Boophilus microplus (Canestrini)) from northern New South Wales. Aust J Agricult Res 1955, 6:666-67I.

35. Murrell A, Campbell NJH, Barker SC: Mitochondrial I2S rDNA indicates that the Rhipicephalinae (Acari: Ixodida: Ixodidae) is paraphyletic. Mol Phylogen Evol 1999, I 2:83-86.

36. Roberts FHS: Australian ticks. CSIRO, Melbourne; 1970:267.
Publish with Biomed Central and every scientist can read your work free of charge

"BioMed Central will be the most significant development for disseminating the results of biomedical research in our lifetime. "

Sir Paul Nurse, Cancer Research UK

Your research papers will be:

- available free of charge to the entire biomedical community

- peer reviewed and published immediately upon acceptance

- cited in PubMed and archived on PubMed Central

- yours - you keep the copyright
BiolMedcentral 